\title{
DATING OF POLAR ICE BY ${ }^{32} \mathrm{Si}$
}

\author{
By Henrik B. Clausen
}

(Geophysical Isotope Laboratory, University of Copenhagen, DK 2200 København,

\begin{abstract}
Si}$ dating of glacier ice has hitherto been complicated by the poor knowledge of the half life. Furthermore, fall-out of bomb-produced ${ }^{32} \mathrm{Si}$ impedes the determination of the specific activity of cosmic-ray produced ${ }^{32} \mathrm{Si}$ in recent precipitation. Measurements on well-dated pre-bomb samples from the Greenland ice sheet establish a calibration for ${ }^{32} \mathrm{Si}$ dating of up to $\mathrm{I}$ ooo year old polar ice samples of the magnitude of I metric ton. If the technique is used on temperate glaciers, samples of pre-bomb deposits (or from after I 970 ) must be collected for comparison with samples of old ice, using an apparent half life of $295 \pm 25$ years. Due to secular cosmic-ray flux variations, the true half life of ${ }^{32} \mathrm{Si}$ is estimated at the slightly higher value of $330 \pm 40$ years.
\end{abstract}

RÉSumÉ. Datation de la glace polaire par ${ }^{32} \mathrm{Si}$. La datation de la glace de glacier au ${ }^{32} \mathrm{Si}$ a, dans le passé, été compliquée par une connaissance imprécise de la période de cet élément. De plus, les retombées de ${ }^{32} \mathrm{Si}$ produites par les bombes nucléaires, gênent la détermination de l'activité spécifique du ${ }^{32} \mathrm{Si}$ produit par le rayonnement cosmique dans les précipitations récentes. Les mesures d'échantillons bien datés, antérieurs à la bombe, provenant de la calotte Groenlandaise, permettent d'établir une échelle pour les datations au ${ }^{32} \mathrm{Si}$ pour des échantillons de glace polaire allant jusqu'à I 000 ans d'âge, et d'un poids de l'ordre de la tonne métrique. Si la technique est employée sur des glaciers tempérés, il faut recueillir des échantillons issus de dépôts antérieurs à la bombe (ou postérieur à 1970) pour les comparer à des échantillons de vieille glace, et tenir compte d'une période de $295 \pm 25$ ans. En raison des variations séculaires du flux de rayonnement cosmique, la véritable période du ${ }^{32} \mathrm{Si}$ est estimée à une valeur légèrement supérieure soit $330 \pm 40$ ans.

Zusammenfassung. Datierung von Polareis mit ${ }^{32} \mathrm{Si}$. Die Datierung von Gletschereis mit ${ }^{32} \mathrm{Si}$ war bisher durch die unvollständige Kenntnis der Halbwertszeit erschwert. Weiter behindern die von Bomben hervorgerufenen ${ }^{32} \mathrm{Si}$-Ausfälle die Bestimmung der spezifischen Aktivität des durch kosmische Strahlung entstehenden ${ }^{32} \mathrm{Si}$ in rezentem Niederschlag. Messungen an genau datierten Proben des grönländischen Inlandeises aus der Zeit vor den Bombenabwürfen erlauben eine Kalibrierung der ${ }^{32} \mathrm{Si}$-Datierung für bis zu $\mathrm{I}$ ooojährigen Polareisproben in der Grössenordnung von einer Tonne. Wenn das Verfahren fùr temperierte Gletscher verwendet werden soll, müssen zum Vergleich mit Proben alten Eises Proben aus Niederschlägen aus der Zeit vor den Bombenabwürfen (oder aus der Zeit nach 1970) gesammelt werden, wobei eine scheinbare Halbwertszeit von $295 \pm 25$ Jahren zu verwenden ist. Infolge der säkularen Schwankungen der kosmischen Strahlung wird die wahre Halbwertszeit von ${ }^{32} \mathrm{Si}$ geringfügig höher auf $330 \pm 40$ Jahre geschätzt.

THE use of cosmic-ray produced ${ }^{32} \mathrm{Si}$ for dating of ice and water (Lal and others, I960; Clausen and others, I968; Lal and others, 1970) has hitherto been complicated by the poor knowledge of the half life. The literature contains several estimates ranging from 60 to 7 Io years (Turkevich and Samuels, 1954; Geithof, I962; Honda and Lal, I964; Jantsch, I967), all of which are based on assumptions about unknown cross-sections of nuclear processes leading to the formation of ${ }^{32} \mathrm{Si}$. Direct measurement of the half life has not been attempted, mainly because of the difficulty in determining the number of ${ }^{32} \mathrm{Si}$ atoms in the small samples obtainable.

This work presents calibration curves for ${ }^{32} \mathrm{Si}$ dating of polar ice, independent of the half life and possible temporal changes in the production rate of ${ }^{32} \mathrm{Si}$. With reasonable assumptions about the production-rate changes, the calibration curves lead to an estimate of the half life, independent of cross-section considerations.

${ }^{32} \mathrm{Si}$ is cosmic-ray produced in the atmosphere by argon spallations (Lal and others, I96o) and is scavenged from the atmosphere by rain and snow. The rate of production has been estimated at $\mathrm{I} .7 \times \mathrm{IO}^{-4}$ atoms $\mathrm{cm}^{-2} \mathrm{~s}^{-1}$ (Lal and others, $\left.\mathrm{I} 96 \mathrm{o}\right)$ and at $\mathrm{I} .2 \times \mathrm{IO}^{-4}$ atoms $\mathrm{cm}^{-2} \mathrm{~s}^{-1}$ assuming a half life of 300 years (cf. Dansgaard and others, ig66[a], p. 5476). At latitudes higher than $30^{\circ}$, the specific ${ }^{32} \mathrm{Si}$ activity of precipitation is expected to be approximately 20 $\mathrm{dph} /$ ton, essentially independent of latitude (Dansgaard and others, ig66[a], p. 5476, [b], fig. I). 
The snow- and ice-pack in the high-altitude regions of the Greenland ice sheet contains many thousands of annual layers of precipitation, accumulated without run-off or mixing. They can be dated by ice-flow considerations (Dansgaard and Johnsen, 1969) or by counting ${ }^{18} \mathrm{O} /{ }^{16} \mathrm{O}$ summer maxima downwards from the surface (Johnsen and others, 1972). A total of I 3 firn and ice samples were collected, melted and chemically prepared for extraction of ${ }^{32} \mathrm{Si}$. Data obtained on these samples are listed in Table I. Comments on the individual columns are given below.

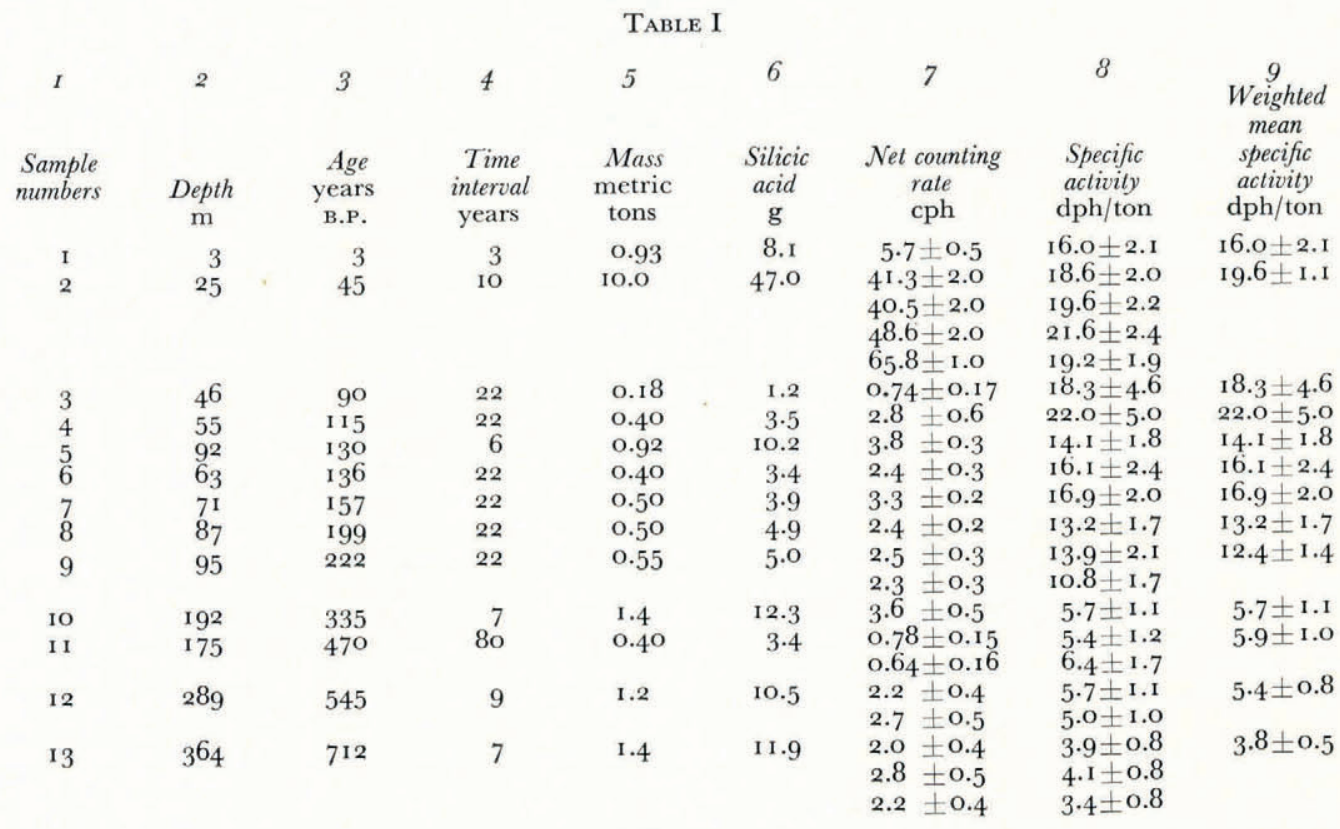

I. Sites of collection. Sample Nos. I-5, I0, I2 and 13 originate from a pit and a bore hole at the Dye 3 station in south Greenland. These bore-hole samples are identical to samples collected for ${ }^{14} \mathrm{C}$ dating by Hans Oeschger's group from the University of Bern $\left({ }^{14} \mathrm{C}\right.$ data will be reported later). The rest of the samples originate from a $100 \mathrm{~m}$ deep trench with slope of I : 3, at Camp Century, north-west Greenland, but No. I I is from a bore hole at the same location.

2. The depth is for Camp Century the distance from the I 966 summer layer to the ice sample in situ, for Dye 3 the distance from the 197 I surface to the sample. In order to exclude contamination with bomb-produced ${ }^{32} \mathrm{Si}$ (Dansgaard and others, I966[a]), the samples were collected from layers below the 1945 horizon, except the surface sample from Dye 3, which represents the accumulation from the summer of 1968 to the summer of $197 \mathrm{I}$. In this period the fall-out of bomb-produced ${ }^{32} \mathrm{Si}$ has dropped to negligible values (Dansgaard and others, 1966[a]).

3. The age $T$ is the time elapsed since the deposition of the samples. As for the Dye 3 samples, the ages are determined by counting summer maxima from the surface in a complete ${ }^{18} \mathrm{O} /{ }^{16} \mathrm{O}$ record spanning $74^{1}$ years. The accuracy of these datings is better than \pm 10 years. The Camp Century samples are dated by using the formula (Dansgaard and Johnsen, r969)

$$
T=\frac{(2 H-h) \tau}{2 \lambda_{H}} \ln \frac{2 H-h}{2 y-h},
$$


$H=\mathrm{I} 367.5 \mathrm{~m}$ of ice being the total thickness of the ice sheet, and $y \mathrm{~m}$ of ice being the present distance of the sample from the bottom, both corrected for the low densities in the upper layers. $h=400 \mathrm{~m}$ is the distance from the bottom, above which the horizontal velocity profile is considered uniform (below $h=400 \mathrm{~m}$ this profile is assumed to vary proportionally to $y$, which is not essential for this work). $\lambda_{H} / \tau=0.35 \mathrm{~m}$ of ice/year is the present annual accumulation rate (Crozaz and Langway, I966) which has been shown to be representative for the entire depth interval considered here (Johnsen and others, 1972, fig. 2). The accuracy of these datings is probably better than $\pm 5 \%$.

4. The time interval $\Delta$ represented in each sample is calculated from the known length of the sample using either the ${ }^{18} \mathrm{O} /{ }^{16} \mathrm{O}$ record or the formula above. Each sample is collected so as to represent many years of snow accumulation in order to smooth seasonal variations in the ${ }^{32} \mathrm{Si}$ deposition rate 3.5 times higher in summer than in winter; Dansgaard and others, I966[b]). Furthermore, whenever possible the samples represent two i I year solar cycles in order to reduce possible influence of short-period variations in the cosmic-ray intensity.

5. Amount of sample. Field preparation. Due to the low specific activity of snow, huge amounts of ice (hundreds of kilograms) are required for dating purposes. In the field, preliminary chemical concentration of ${ }^{32} \mathrm{Si}$ takes place in drums containing the melt water, acid $\mathrm{FeCl}_{3}$ solution and inactive silica carrier. Addition of ammonia in excess produces a precipitate of $\mathrm{Fe}(\mathrm{OH})_{3}$, which scavenges all silica from the water. The field preparation is completed by concentration of the precipitate by filtration.

6. The silicic acid is recovered from the precipitate in the laboratory. After drying, the iron and silicon components are separated in boiling hydrochloric acid. To bring all silica into a soluble state, the remaining precipitate is melted in liquid sodium hydroxide (at $c .320^{\circ} \mathrm{C}$ ) containing a few per cent of sodium nitrate to oxidize possible organic contaminants. After recovering the silicon components as silicic acid by adding hydrochloric acid to the melt dissolved in water, it is heated to $800^{\circ} \mathrm{C}$ in an electric oven.

7. The net counting rate. The radioactivity measurements are carried out on the daughter ${ }^{32} \mathrm{P}$, because it is better suited for detection due to its high $\beta$ energy $\mathrm{I} .7 \mathrm{MeV}$ (compared with o. I MeV for ${ }^{32} \mathrm{Si}$ ), and for identification due to the short and well-known half life of $\mathrm{I} 4.3 \mathrm{~d}$. During 2 months of storage, the ignited silicic acid builds up ${ }^{32} \mathrm{P}$ to more than $95 \%$ of the equilibrium value. The chemical extraction of ${ }^{32} \mathrm{P}$ from the silicic acid has been described in detail by Lal and others ( 1960 ). The $\beta$ measurement is carried out on approximately I $5 \mathrm{mg}$ of $\mathrm{Mg}_{2} \mathrm{P}_{2} \mathrm{O}_{7}$ in a small counter of the Lal type (Lal and Schink, I96o) modified by S. J. Johnsen. The counter background is $\approx \mathrm{I} .5 \mathrm{cph}$ for a counting area of $0.5 \mathrm{~cm}^{2}$. The counting efficiency is approximately $50 \%$ for a $2 \pi$ geometry with o. I mm tungsten backscattering. Figure $\mathrm{I}$ gives

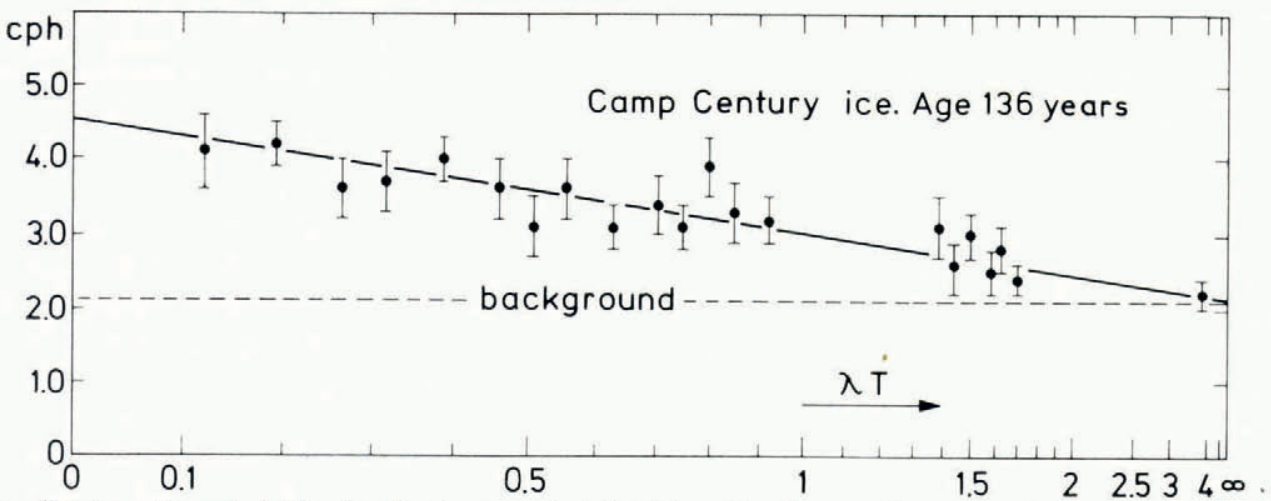

Fig. 1 . Total counting rate $(c p h)$ of a phosphate sample isolated from the silicates. The net counting rate is due to the 32 Si daughter ${ }^{32} P$ that is built up close to equilibrium after 2 months. The ${ }^{32}$ Si activity of the ice sample is calculated from the net counting rate for $T=0$ after correction for counter efficiency, etc. 
an example of the total counting rate of sample 6 plotted as a function of exp $(-\lambda T), \lambda$ being the decay constant of ${ }^{32} \mathrm{P}$ and $T$ the time since separation of ${ }^{32} \mathrm{P}$ from the silica. The straight line is determined by the method of least squares. The difference between the intersection of this line with ordinates for $T=0$ and $T=\infty$ gives the net counting rate of the sample at the time of isolation. The ordinate for $T=\infty$ gives the background of the counter plus the contribution of possible long-lived impurities.

8. The specific activity is obtained from columns 5 and 7 after correction for counter efficiency and chemical yield. The stated uncertainties include the uncertainties on the latter parameters.

9. The weighted mean specific activities are plotted versus age $T$ in Figure 2. The (extrapolated) surface value is $23 \pm 2 \mathrm{dph} /$ ton at Camp Century and $\mathrm{r} 6.5 \pm 1.5 \mathrm{dph} /$ ton at Dye 3 . The former value may be representative for north and north-west Greenland, because another sample from mid north Greenland (Inge Lehmann) indicates $27 \pm 3 \mathrm{dph} /$ ton. Similarly, the Dye 3 value may be representative for East and south Greenland, because a sample from mid East Greenland (Jarl Joset) indicates $19 \pm 3 \mathrm{dph} /$ ton.

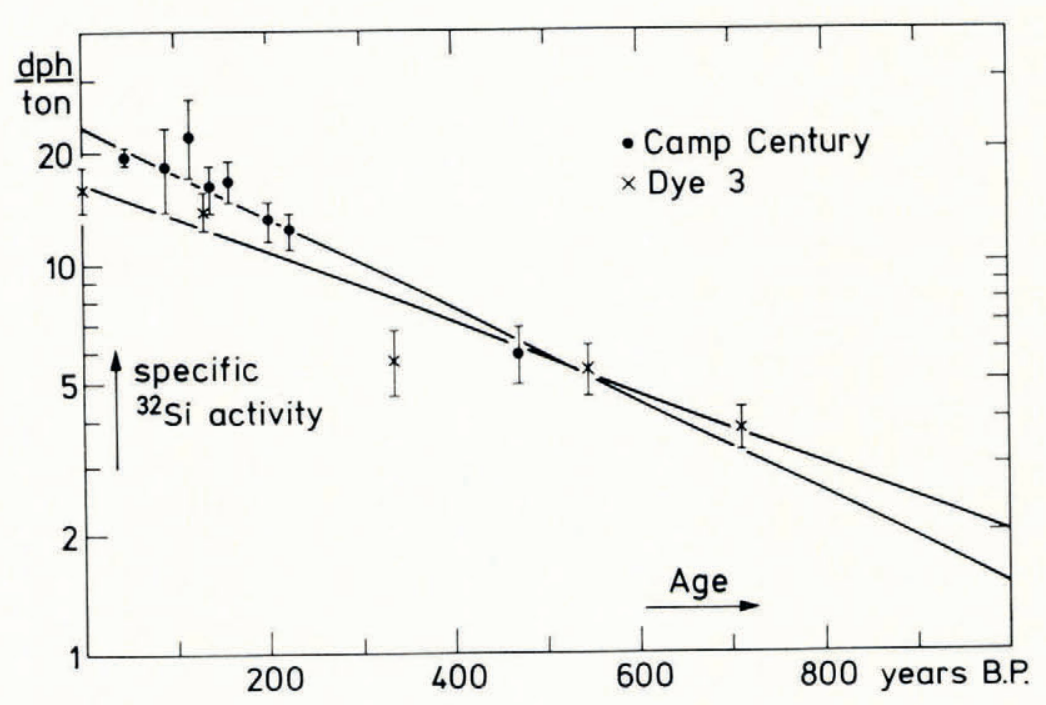

Fig. 2. The specific ${ }^{32}$ Si activity (disintegrations per hour per ton) of firn and ice samples plotted as a function of the time since deposition. Dating of old ice should be based on the apparent half life of 295 years and on the specific activity of a sample of recent deposits.

The two lines are calculated by the method of least squares. The slopes of the two lines correspond to apparent half lives of $260 \pm 40$ and $330 \pm 35$ years for ${ }^{32} \mathrm{Si}$. The difference is not significant and $295 \pm 25$ years is adopted as the best estimate of the apparent half life of ${ }^{32} \mathrm{Si}$ for dating of ice in Greenland. As to west Antarctic ice, the same apparent half life can probably be used along with a specific ${ }^{32} \mathrm{Si}$ activity of recent precipitation of $25 \pm 2 \mathrm{dph} /$ ton, as indicated by a preliminary measurement on pre-bomb firn from "Byrd" station.

When used on up to I ooo year old ice samples of the order of I ton, the technique described above gives datings with an estimated uncertainty of \pm 60 years. Ice older than $\mathrm{I}$ ooo years may be dated by using correspondingly higher amounts (a factor of 2 higher for each 300 years beyond I ooo years). 
Measurements on recent material from temperate glaciers in Norway (Dansgaard and others, I966[b]) and Austria (Clausen and others, I968) gave somewhat higher values (28 and $5^{\circ} \mathrm{dph} /$ ton). These samples were collected in 1962 and 1966 respectively and were probably contaminated with bomb-produced ${ }^{32} \mathrm{Si}$. Therefore, if the technique is applied outside Greenland and west Antarctica, a recent reference sample should be collected so as to represent net accumulated material from prior to 1952 , or, if impossible, after 1970, assuming negligible fall-out of bomb-produced ${ }^{32} \mathrm{Si}$ in the present decade. If only a short time interval of deposition can be represented, it must be a whole number of years. In all cases, any kind of solid matter present in the samples should be included in the chemical preparation to account for possible adhesion of ${ }^{32} \mathrm{Si}$ to solid particles.

The apparent half life of $295 \pm 25$ years, suggested by the data in Figure 2, should be applied for dating of cold as well as temperate glaciers.

The true half life of ${ }^{32} \mathrm{Si}$ is probably a little higher due to secular changes of the cosmic-ray flux and, therefore, of the natural ${ }^{32} \mathrm{Si}$ production in the atmosphere. Unfortunately, the temporal change in the cosmic-ray flux is still an unsolved problem. However, short time variations (i.e. up to several hundred years) would show up in Figure 2, if essential. For example, one may expect that the 400 year oscillation observed in the ${ }^{14} \mathrm{C} /{ }^{12} \mathrm{C}$ ratio in tree rings (Suess, 1970) would appear in Figure 2, if due to cosmic-ray flux variations, the more so as the ${ }^{32} \mathrm{Si}$ fall-out is not subject to attenuation, as is the ${ }^{14} \mathrm{C} /{ }^{12} \mathrm{C}$ ratio in the atmosphere (due to $\mathrm{CO}_{2}$ exchange with the oceans). The reason why the data do not oscillate with a period of 400 years may be either that the corresponding variation in the ${ }^{14} \mathrm{C} /{ }^{12} \mathrm{C}$ ratio is not caused by varying cosmic-ray flux or that the cosmic-ray component producing ${ }^{32} \mathrm{Si}$ varies much less than that producing ${ }^{14} \mathrm{C}$.

On the other hand, the slope of the line in Figure 2 may be influenced by the long-term variation (8 goo year period) in the cosmic-ray flux caused by oscillating geomagnetic moment (Bucha and Neustrupny, 1967). During the last 700 years the geomagnetic moment seems to have decreased by $25 \%$ (Bucha, I970), which corresponds to a $10 \%$ increase of the ${ }^{14} \mathrm{C}$ production, according to Lal and Venkatavarandan's (1970, fig. 4) calculations.

Let us assume that the production and fall-out of ${ }^{32} \mathrm{Si}$ has also increased by $10 \%$. This means that the half life of $295 \pm 25$ years from Figure 2 is a little lower than in the case of the unchanged ${ }^{32} \mathrm{Si}$ production rate. The corrected half life therefore appears to be $33^{\circ} \pm 40$ years, the higher uncertainty being used to account for the difficulty in estimating the correction term.

\section{Acknowledgements}

Several people have contributed to the completion of this work. First of all I wish to thank W. Dansgaard and S. J. Johnsen for unlimited help in all phases of the work. Thanks are also due to Claus Hammer, Kjeld Rasmussen, Jørgen Stougaard and Jørgen Wilhjelm (Copenhagen), to Peter Bucher, Markus Möll, Hans Oeschger, Heinrich Rufli and Bernhard Stauffer (University of Bern) ; Lyle Hansen, Chester Langway and Wilford Weeks (U.S.A. C.R.R.E.L., New Hampshire); Michel Pourchet (E.G.I.G.) and Ralph Lenton (Arctic Institute of North America), all of whom helped me in the field. Peter Fauslund (Danish Arctic Contractors) and Jørgen Mølgaard (Danish Liaison Officer) made it possible for me to work at Thule A.B. Financial support was granted by the Ministry of Greenland, the Carlsberg Foundation (Copenhagen) and the U.S. National Science Foundation (Office of Polar Programs, Washington).

\section{MS. received 31 October 1972}




\section{REFERENCES}

Bucha, V. 1970. Influence of the Earth's magnetic field on radiocarbon dating. (In Olsson, I. U., ed. Nobel Symposium 12. Radiocarbon variations and absolute chronology. New York, John Wiley and Sons, Inc., p. 501-1 I.)

Bucha, V., and Neustupny, E. 1967. Changes of the Earth's magnetic field and radiocarbon dating. Nature, Vol. 2 i 5 , No. 5098, p. $26 \mathrm{i}-63$.

Clausen, H. B., and others. 1968 . $\mathrm{Si}^{32}$ dating of an Alpine glacier, by H. B. Clausen and B. Buchmann [and] W. Ambach. Union de Géodésie et Géophysique Internationale. Association Internationale d'Hydrologie Scientifique. Assemblée générale de Berne, 25 sept.-7 oct. I967. [Commission de Neiges et Glaces.] Rapports et discussions, p. 135-40.

Crozaz, G., and Langway, C. C., jr. ig66. Dating Greenland firn-ice cores with Pb-2 ro. Earth and Planetary Science Letters, Vol. I, No. 4, p. 194-96.

Dansgaard, W., and Johnsen, S. J. I 969 . A flow model and a time scale for the ice core from Camp Century, Greenland. Journal of Glaciology, Vol. 8, No. 53, p. $215^{-23}$.

Dansgaard, W., and others. I966[a]. Evidence for bomb-produced silicon 32, by W. Dansgaard, H. B. Clausen and A. Aarkrog. Fournal of Geophysical Research, Vol. 71, No. 2, p. 5474-77.

Dansgaard, W., and others. $1966[\mathrm{~b}]$. The $\mathrm{Si}^{32}$ fallout in Scandinavia: a new method for ice dating, by W. Dansgaard, H. B. Clausen and A. Aarkrog. Tellus, Vol. 18, Nos. 2-3, p. 187-91.

Geithoff, D. 1962. Uber die Herstellung von $\mathrm{Si}^{32}$ durch einen (t, p)-Prozess. Radiochimica Acta, Bd. I, Ht. I, p. 3-6.

Honda, M., and Lal, D. 1964. Spallation cross sections for long-lived radionucleides in iron and light nuclei. Nuclear Physics, Vol. 51, No. 3, p. 363-68.

Jantsch, K. 1967 . Kernreaktionen mit Tritonen beim ${ }^{30} \mathrm{Si}$ : Bestimmung der Halbwertzeit von ${ }^{32} \mathrm{Si}$. Kernenergie, Io. Jahrg., Ht. 3, p. 89-9i.

Johnsen, S. J., and others. 1972. Oxygen isotope profiles through the Antarctic and Greenland ice sheets, [by] S. J. Johnsen, W. Dansgaard, H. B. Clausen, C. C. Langway, Jr. Nature, Vol. 235, No. 5339, p. 429-34.

Lal, D., and Schink, D. R. 1960. Low background thinwall flow counters for measuring beta activity of solids. Review of Scientific Instruments, Vol. 31, No. 4, p. 395-98.

Lal, D., and Venkatavaradan, V. S. 1970. Analysis of the causes of $\mathrm{C}^{14}$ variations in the atmosphere. (In Olsson, I. U., ed. Nobel Symposium 12. Radiocarbon variations and absolute chronology. New York, John Wiley and Sons,

Inc., p. 549-69.)
Lal, D., and others. 1960. Cosmic-ray-produced silicon-32 in nature, by D. Lal, E. D. Goldberg and M. Koide. Science, Vol. 131, No. 3397, p. 332-37.

Lal, D., and others. $1970 . \mathrm{Si}^{32}$ hydrology, by D. Lal, V. N. Nijampurkar and S. Rama. (In Isotope hydrology 1970. Proceedings of a symposium on use of isotopes in hydrology held by the International Atomic Energy Agency in co-operation with the United Nations Educational, Scientific and Cultural Organization in Vienna, 9-13 March I97o. Vienna, International Atomic Energy Agency, p. 847-68.)

Suess, H. E. 1970. Bristlecone-pine calibration of the radiocarbon time-scale 5200 B.C. to the present. (In Olsson, I. U., ed. Nobel Symposium 12. Radiocarbon variations and absolute chronology. New York, John Wiley and

Sons, Inc., p. $303-11$.
Turkevich, A., and Samuels, A. 1954. Evidence for $\mathrm{Si}^{32}$ a long lived $\beta$-emitter. Physical Review, Second Ser., Vol. 94, No. 2, p. 364 . 